\title{
Frequency of disordered calcium metabolism in sarcoidosis
}

\author{
HAROLD L. ISRAEL \\ ROBERT A. Goldstein
}

\author{
Sarcoidosis Clinic, Thomas Jefferson University Hospital, Philadelphia \\ and the Veterans Administration Hospital, Washington
}

\section{Summary}

A prospective study of total and ultrafiltrable serum calcium levels in 121 patients with sarcoidosis and thirty-eight control subjects revealed no significant differences. Two patients had hypercalcaemia (11.6 and $12.2 \mathrm{mg} \%$ ) at the time of initial sampling; one spontaneously returned to normal. Retrospective analysis of 318 cases previously studied demonstrated persistent hypercalcaemia in eight of 262 negroes and two of fifty-six whites, with a male to female ratio of seven to three.

Serial calcium measurements in thirty-four patients and single determinations in eighty-seven patients taken during the course of 1 year failed to show seasonal fluctuation.

These observations suggest that calcium metabolism is normal in most patients with sarcoidosis. When persistent hypercalcaemia is found in a patient with sarcoidosis, careful study for associated hyperparathyroidism is essential, especially if the sarcoidosis is otherwise asymptomatic or inactive.

Hypercalcaemia was first recognized in patients with sarcoidosis 30 years ago, and quickly became established as an important and frequent manifestation of the disease. Estimates of its prevalence have varied widely but rates of $30 \%$ or more have often been described and disordered calcium metabolism is generally regarded as a characteristic feature of sarcoidosis, demonstrable by hypercalciuria or balance studies if not always by elevated serum levels.

A review of our own patients, however, showed significant hypercalcaemia to be infrequent (Israel et al., 1961). Other investigators with wide experience in sarcoidosis have also found hypercalcaemia to be uncommon (Putkonen, Hannuksela \& Halme, 1965; Scadding, 1967). When Hahnemann and his associates (1967) reported that raised levels of ionized calcium occurred more frequently than elevations of total calcium, a prospective study of diffusible and total calcium levels was instituted in patients under observation in Philadelphia (Goldstein et al., 1969).
Serum samples from 121 patients with sarcoidosis were examined. These included seventy-four negro women, thirty-one negro men, nine white women and seven white men. Thirty-eight healthy hospital workers similar in age were studied to establish control values.

The mean serum calcium level in negro patients with subacute sarcoidosis was $10.15 \mathrm{mg} / 100 \mathrm{ml}$; $10.03 \mathrm{mg} / 100 \mathrm{ml}$ in those with chronic sarcoidosis and $10.27 \mathrm{mg} / 100 \mathrm{ml}$ in those with inactive disease. The mean level in white patients was $9.99 \mathrm{mg} / 100 \mathrm{ml}$. These levels were not significantly different from those in healthy controls $(10.30 \mathrm{mg} / 100 \mathrm{ml})$.

Two of the 121 patients had initial serum calcium levels above $11.5 \mathrm{mg} / 100 \mathrm{ml}$ (the range in controls being $9 \cdot 12 \mathrm{mg} / 100 \mathrm{ml}-11.48 \mathrm{mg} / 100 \mathrm{ml}$ ). In one case the elevation was transient; in the other instance, that of an acutely ill patient, levels in 2 consecutive months were raised and prednisone treatment instituted.

Thirty-four patients had serial measurements and five, whose initial values were normal, showed elevations on subsequent examinations. In four cases, repeat samplings were normal. One patient had two elevations a month apart and was immediately hospitalized for study; all urinary and blood measurements in the hospital were normal.

To determine seasonal variations in calcium levels, single determinations in eighty-seven patients and 147 serial measurements in thirty-four patients were tabulated. The mean serum level in September $(10.74 \mathrm{mg} / 100 \mathrm{ml})$ was significantly higher than in October $(9.56 \mathrm{mg} / 100 \mathrm{ml})$ but was not different from any other month. Of the eight elevations encountered, two occurred in September, two in November, and the others were scattered through the rest of the year.

Mean ultrafiltrable levels of calcium in seventyseven patients were slightly higher $(6 \cdot 11 \mathrm{mg} / 100 \mathrm{ml})$ than in controls $(5.81 \mathrm{mg} / 100 \mathrm{ml})$; the difference is not statistically significant.

A retrospective analysis was made of serum calcium measurements in 318 patients with sarcoidosis studied prior to 1966 . This group comprised 
262 negroes and fifty-six whites. Persistent hypercalcaemia (two consecutive levels greater than $11.5 \mathrm{mg} / 100 \mathrm{ml}$ ) was found in three of 184 negro women and five of seventy-eight negro men. An additional fifteen women and twelve men had transient elevations.

Persistent hypercalcaemia occurred in two of twenty-eight white men, transient elevations in two other men and two of twenty-eight women.

\section{Discussion}

The reported frequency of hypercalcaemia in sarcoidosis varies widely not only among countries but also within countries. In some studies only single calcium determinations were made; in others, where multiple measurements were made, a larger number of elevations was observed. It appears that transient slight rises of calcium accounted for most of the reported elevations. The upper limit of normal was often chosen without benefit of control subjects and ranged from $10.5 \mathrm{mg} / 100 \mathrm{ml}$ to $12.0 \mathrm{mg} / 100 \mathrm{ml}$.

Israel and his associates (1961) reported calcium levels in 160 patients, regarding $11.5 \mathrm{mg} / 100 \mathrm{ml}$ or higher as abnormal. Six patients $(3.8 \%)$ had sustained hypercalcaemia and thirty-nine $(24 \cdot 4 \%)$ had transient rises. Fifty-six patients in whom a diagnosis of sarcoidosis could not be established acted as controls. Transient elevations occurred in ten $(17.9 \%)$. It was suggested that technical variations in a routine laboratory were responsible for most transient slight elevations. Keating et al. (1969) in a study of healthy white subjects between 20 and 50 years of age reported no values above $10.2 \mathrm{mg} /$ $100 \mathrm{ml}$ or below $8.5 \mathrm{mg} / 100 \mathrm{ml}$, but values in the routine laboratory which exceeded these limits, representing $10-30 \%$ of specimens, where either repeated or discarded.

It appears that transient elevations are more common than is generally appreciated; these occasional elevations may be related to diet or to technical variations.

If sustained elevation of calcium in the blood is infrequent, evidence that calcium metabolism is commonly abnormal in sarcoidosis has come from urinary studies and from balance studies. Although it is widely considered that a majority of patients with sarcoidosis have hypercalciuria, there are few reports of 24-hr urinary collections on a controlled calcium intake. Putkonen et al. (1965) found hypercalciuria (24-hr excretion greater than than $300 \mathrm{mg}$ ) in $15 \%$ of thirty-nine patients with sarcoidosis compared to $6 \%$ in controls. Mean values of calcium were identical in the two groups. Nordin, Hodgkinson $\&$ Peacock (1967) have recently emphasized the rapid changes in urinary excretion of calcium dependent upon calcium intake. We have instituted metabolic studies in the Clinical Research Center of Jefferson
Hospital. Two negro men have thus far been studied: Daily urinary excretion on a $1200 \mathrm{mg}$ calcium intake has been in Case 1, 153, 177 and $169 \mathrm{mg}$, and in Case 2, 263, 223 and $331 \mathrm{mg}$.

Most metabolic studies have been limited to sarcoidosis patients with manifest calcium disturbances. The well-known investigations of Anderson et al. (1954), Henneman et al. (1956), Mather (1957), Jackson \& Dancaster (1959) and Bell, Gill \& Bartter (1964) comprise a total of twelve patients with both hypercalcaemia and hypercalciuria, and three with hypercalciuria; many had impaired renal function. In these patients, low faecal calcium was consistently demonstrated, supporting the theory that calcium absorption from the gut is increased in sarcoidosis. Different findings were noted by Hendrix (1966) whose five patients included three with normal serum and urine calcium values. In no instance was faecal calcium lowered, and he concluded that osseous involvement was responsible for the hypercalcaemia, a view shared by Hunt \& Yendt (1963) whose hypercalcaemic patient had high faecal calcium levels.

Studies of the pathophysiology of the calcium disturbance that exists in some patients with sarcoidosis are thus inconclusive. Nevertheless, most investigators have accepted the concept that patients with this disease are abnormally sensitive to vitamin D. Evidence for this view includes reports of toxicity from use of calciferol in sarcoidosis (Scadding, 1950; Mather, 1957), observations of adverse effects of sunlight (Ellman \& Parfitt, 1960) and the report of increased frequency of hypercalcaemia in summer months (Taylor et al, 1963). The effect of sunlight, however, has not been confirmed in two prospective studies; the toxic effects of calciferol may be independent of hypercalcaemia (Robertson, 1948); and we have used calciferol in treatment of several patients with disfiguring cutaneous sarcoids; no increases in calcium levels occurred.

Our finding of almost universally normal serum levels of total and ultrafiltrable calcium makes it improbable that sub-clinical disturbance of calcium metabolism is widespread in sarcoidosis. Moreover, when hypercalcaemia is observed in a patient with sarcoidosis, serious consideration must be given to the co-existence of hyperparathyroidism. The occurrence of parathyroid adenomas in patients with sarcoidosis has been the subject of twelve case reports (Winnacker et al., 1969); and Dent \& Watson (1966) have pointed out that the association may be more than coincidental.

This is not to suggest that sarcoidosis cannot cause hypercalcaemia. In a total of 381 patients (combined prospective and retrospective data), we have encountered eleven with persistent elevation of serum calcium in whom hyperparathyroidism 
can be excluded on the basis of necropsy findings or recovery without parathyroidectomy. An analysis of these cases indicates that in each instance there was obvious clinical activity manifested by fever, acute splenic or glandular enlargement, and pulmonary spread. The clinical observation that hypercalcaemia in patients with quiescent or asymptomatic sarcoidosis is indicative of hyperparathyroidism deserves strong emphasis.

\section{References}

Anderson, J., Dent, C.E., Harper, C. \& Philpot, G.R. (1954) Effect of cortisone on calcium metabolism in sarcoidosis with hypercalcaemia. Possibly antagonistic actions of cortisone and vitamin D. Lancet, ii, 720.

Bell, N.H., Gill, J.R. JR \& BartTer, F.C. (1964) On the abnormal calcium absorption in sarcoidosis. American Journal of Medicine, 36, 500.

DENT, C.E. \& Watson, L. (1966) Hyperparathyroidism and Sarcoidosis. British Medical Journal, 1, 646-649.

Ellman, P. \& Parfitt, A.M. (1960) The resemblance between sarcoidosis with hypercalcaemia and hyperparathyroidism. British Medical Journal, 2, 108.

Goldstein, R.A., ISRAEL, H.L., Becker, K.L. \& Moore, C.F. (1970) Infrequency of hypercalcaemia in sarcoidosis. (To be published.)

Hahnemann, S., Transbøl, I. \& Hornum, I. (1967) The serum calcium fractions in hypercalcaemic sarcoidosis with and without hyperparathyroidism. La Sarcoidose, Rapports de la IV Conférence internationale, Paris, 605-609. Masson et Cie, Paris.

HeNDRIX, J.Z. (1966) Abnormal skeletal mineral metabolism in sarcoidosis. Annals of Internal Medicine, 64, 797.

Henneman, P.H., Dempsey, E.F., Carroll, E.L. \& Albright, F. (1956) The cause of hypercalciuria in sarcoid and its treatment with cortisone and sodium phytate. Journal of Clinical Investigation, 35, 1229-42.
HunT, B.J. \& YendT, E.R. (1963) The response of hypercalcaemia in sarcoidosis to chloroquine. Annals of Internal Medicine, 59, 554.

IsRael, H.L., Sones, M., Roy, R.L. \& Stein, G.N. (1961) The occurrence of intrathoracic calcification in sarcoidosis. American Review of Respiratory Diseases, 84, 1-11.

JACKSON, W.P.U. \& DANCASTER, C. (1959) A consideration of the hypercalciuria in sarcoidosis, idiopathic hypercalciuria, and that produced by vitamin $\mathrm{D}$; a new suggestion regarding calcium metabolism. Journal of Clinical Endocrinology, 19, 658-80.

Keating, F.R., Jones, J.D., Elveback, L.R. \& Randall, R.V. (1969) The relation of age and sex to distribution of values in healthy adults of serum calcium, inorganic phosphorus, magnesium, alkaline phosphatase, total proteins, albumin and blood urea. Journal of Laboratory and Clinical Medicine, 73, 825.

Mather, G. (1957) Calcium metabolism and bone changes in sarcoidosis. British Medical Journal, 1, 248-53.

Nordin, B.E.C., Hodgkinson, A. \& Peacock, M. (1967) The measurement and the meaning of urinary calcium. Clinical Orthopaedics and Related Research, 52, 293.

Putkonen, R., Hannuksela, M. \& Halme, H. (1965) Calcium and phosphorus metabolism in sarcoidosis. Acta medica Scandinavica, 177, 327.

Robertson, R.F. (1948) Vitamin D in the treatment of Boeck's sarcoid. British Medical Journal, 2, 1059-61.

SCadding, J.G. (1950) Sarcoidosis with special reference to lung changes. British Medical Journal, 1, 745-53.

Scadding, J.G. (1967) Sarcoidosis, Eyre \& Spottiswoode, London, p. 341.

TAYLOR, R.L., LYNCH, H.J. JR \& WYSOR, W.G. JR (1963) Seasonal influence of sunlight on the hypercalcemia of sarcoidosis. American Journal of Medicine, 34, 221-7.

WinNACKer, J.L., BeCKer, K.L., Friedlander, M., Higgins, G.A. JR \& MOORE, C.F. (1969) Sarcoidosis and hyperparathyroidism. American Journal of Medicine, 46, 305. 